\title{
Comparison of energy intensity of different food materials and their energy content
}

\author{
1,*Maysami, M.A. and ${ }^{2}$ Berg, W. \\ ${ }^{1}$ Biosystems Engineering Department, Faculty of Agriculture, University of Tabriz, $29^{\text {th }}$ Bahman \\ Avenue, 5166616471 Tabriz, Iran \\ ${ }^{2}$ Leibniz-Institute for Agricultural Engineering and Bioeconomy e.V. (ATB), Max-Eyth-Allee 100, 14469 \\ Potsdam, Germany
}

\author{
Article history: \\ Received: 11 May 2020 \\ Received in revised form: 24 \\ October 2020 \\ Accepted: 28 March 2021 \\ Available Online: 3 April \\ 2021
}

Keywords:

Cereals,

Energy content,

Energy intensity,

Meat,

Milk

DOI:

https://doi.org/10.26656/fr.2017.5(S1).043

\begin{abstract}
The energy embodied in different food materials refers to energy input in its production in agricultural and or livestock farms in direct or indirect forms. In this work, it is intended to make a comparison among the energy intensity of cereals, cow milk and bull meat production. The study was performed to evaluate the energy flow in dairy farms and related feedstuff production farms in the northwest of Iran. According to the results, the energy intensity of wheat and maize corn is 4.35 and $9.19 \mathrm{MJ} \mathrm{kg}^{-1}$, respectively, while they have the energy content of nearly $15 \mathrm{MJ} \mathrm{kg}^{-1}$ as food materials with almost $15 \%$ moisture content. The energy intensity of ECM milk was calculated to be $5.81 \mathrm{MJ} \mathrm{kg}^{-1}$, while it has the energy content of only $3.15 \mathrm{MJ} \mathrm{kg}^{-1}$, with a water content of $87.2 \%$. As for boneless meat, for a bull mass of up to $400 \mathrm{~kg}$, the energy intensity was $75.4 \mathrm{MJ} \mathrm{kg}^{-1}$ while it was $103.8 \mathrm{MJ} \mathrm{kg}^{-1}$ for bulls up to $700 \mathrm{~kg}$ body mass. It is much higher than for milk and cereals, while, it has only $8.8 \mathrm{MJ} \mathrm{kg}^{-1}$ energy content for the fresh state with nearly $70 \%$ water content. A comparison of these energy values indicates the high use of resources, harmful to the environment, for products of animal origin, especially for meat. This issue will get worse with an increasing demand for animal products in the future. Therefore, replacing bull meat with less energy-intensive food materials such as cereals and other meat, e.g. poultry, could reduce pressure on the environment.
\end{abstract}

\section{Introduction}

More than 3.7 billion people in the world were faced with malnourishment (Pimentel, 2009). In 2010, it was determined that of these 3.7 billion, 925 million people, mostly in developing countries, were undernourished, increasing worldwide since 1995 (FAO and WFP, 2010). Poverty and undernourishment of a large part of the population are caused by fundamental problems in the distribution of food and resources, otherwise, agriculture produces enough food to overcome future demands (FAO, IFAD and WFP, 2002).

The increase in demand for livestock products is growing more rapidly than the population growth rate (Schneider, 2010), because of increasing living standards and shifting demographic parameters (Steinfeld et al., 2006). Global production of milk and meat in 2050 is projected to be more than double the production of 1999 (Steinfeld et al., 2006), an increase that is being called the Livestock Revolution (Devendra, 2002). By efforts to increase food productions, more intensive use of energy in agricultural systems is unavoidable. Producing enough food by agriculture, especially in the form of livestock products has seriously challenged agriculture by environmental and resources restrictions problems.

Energy efficiency improvement is one of the most important aspects in regard to combatting these challenges. Energy efficiency improvement contributes to the reductions of emissions and climate change (Varone and Aebischer, 2001) and is a solution for fuel resource restrictions. One of the aspects of energy efficiency improvements in the use or consumption of products as well as food materials with lower energy intensity. Energy intensity is the primary energy embodied in materials production mostly revealed in MJ per kg of agricultural products. On the other hand, the energy output from food materials for the human body is quite different for agricultural and livestock products. Besides efforts to reduce the energy intensity of food production, consumption of food materials with lower 
energy intensity and higher energy content would strongly suggest helping to overcome malnourishment, environmental issues and energy restrictions. Therefore, the energy output to input ratio could be well defined as an important index in food materials comparison by energy perspective.

Energy input in farms mainly refers to energy from tractor fuel and irrigation facilities and energy consumed in the production of fertilisers, pesticides and seeds. In the same way, energy input in livestock production refers to indirect energy input from feedstuffs and materials and direct energy of fuels and electricity consumed inside livestock farms. Energy intensity depends on production practices varying significantly from farm to farm and region to region. According to Stanton and LeValley (2010) and Feedipedia (2012), the energy content of cereals is nearly $15 \mathrm{MJ} \mathrm{kg}^{-1}$ (with a moisture content of $15 \%$ ). For milk, it is $3.15 \mathrm{MJ} \mathrm{kg}^{-1} \mathrm{ECM}$ (ECM $=$ energy corrected milk with $4 \%$ fat and $3.4 \%$ protein which has $12.8 \%$ dry matter; Ulbrich et al., 2004) and 8.8 $\mathrm{MJ} \mathrm{kg}^{-1}$ for boneless fresh meat (Klinge, 1989) with approximately $75 \%$ moisture. The energy efficiency of livestock production is lower than that of crop production (Pimentel, 2009). Because conversion ratios of primary energy to the product in animals are significantly less than that for photosynthesis in crops.

A plentiful study about the energy intensity of agricultural products (feedstuffs, cereals etc.) has been carried out. Their results vary widely. The differences in results come from different cultivation methodology, environment and also study methods.

The energy intensity calculated by Refsgaard et al. (1998) for cereals in Denmark was approximately 2.6 MJ $\mathrm{kg}^{-1} \mathrm{DM}$ with a yield of 3,000-4,000 $\mathrm{kg} \mathrm{ha}^{-1}$. In studies in Iran, it was found that the energy intensity of wheat is from 5.4 $\mathrm{MJ} \mathrm{kg}^{-1}$ (Ghobadifar, 2009) to $17.8 \mathrm{MJ} \mathrm{kg}^{-1}$ (Ziaei et al., 2015). The average energy intensity for several studies in wheat cultivation in Iran was found to be $8.3 \mathrm{MJ} \mathrm{kg}^{-1} \mathrm{FM}$ by an average yield of $4.5 \mathrm{t} \mathrm{ha}^{-1}$ (Mohammadi et al., 2015) much higher than reported by Refsgaard et al. (1998). For maize corn, the energy intensity was calculated from $4.6 \mathrm{MJ} \mathrm{kg}{ }^{-1} \mathrm{FM}$ (Feizbakhshi and Soltani, 2013) to $17.5 \mathrm{MJ} \mathrm{kg}^{-1}$ (Sami et al., 2014) for Iran. The average energy intensity of 9.9 $\mathrm{MJ} \mathrm{kg}^{-1}$ FM maize corn with an average yield of $6.4 \mathrm{t} \mathrm{ha}^{-}$ ${ }^{1}$ was calculated by Mohammadi et al. (2015). It seems higher than $5.1 \mathrm{MJ} \mathrm{kg}^{-1}$ maize corn reported by Frorip et al. (2012) for Estonia. The energy intensity calculated for rapeseed was 9.1-10.7 $\mathrm{MJ} \mathrm{kg}^{-1} \mathrm{DM}$ for a study in Iran by Mousavi-Avval et al. (2011) with a yield of $1.9 \mathrm{tha}^{-1}$ FM and much higher than for Germany $\left(5.2 \mathrm{MJ} \mathrm{kg}^{-1}\right.$ DM) estimated by Kraatz (2009).
The energy intensity of milk production for dairy farms in European countries was reported by some studies. The high share of energy input from feedstuffs makes the energy intensity of feedstuffs the main determinative factor in the energy intensity of milk. Refsgaard et al. (1998) found that $70 \%$ of the energy input in milk production is from feedstuffs, $20 \%$ from direct energies and 10\% from facilities (e.g. building and machinery) resulted in energy intensity of $3.3 \mathrm{MJ} \mathrm{kg}^{-1}$ ECM in Denmark. Kraatz (2009) found it to be $3.5 \mathrm{MJ}$ $\mathrm{kg}^{-1}$ ECM and Abel (1997) calculated it as $4.4 \mathrm{MJ} \mathrm{kg}^{-1}$, both for Germany. Williams et al. (2006) determined an energy intensity of $2.5 \mathrm{MJ} \mathrm{kg}^{-1}$ fresh milk in the UK.

The energy intensity of beef meat production in Germany for conventional keeping systems was 56.35 $\mathrm{MJ} \mathrm{kg}^{-1}$ and $25.50 \mathrm{MJ} \mathrm{kg}^{-1}$ for organic systems according to the data from GEMIS 3.1 (Taylor, 2000). In the UK, the energy intensity of cattle meat production was estimated to be $28 \mathrm{MJ} \mathrm{kg}^{-1}$ of the carcass mass (Williams et al., 2006). Frorip et al. (2012), calculated the energy intensity for meat as $69 \mathrm{MJ} \mathrm{kg}^{-1}$ for Estonia.

In comparison to crop production, few studies have been conducted on the energy efficiency of livestock farming (Wechselberger, 2000) and there is a scarcity of data for energy intensity of meat and milk production. This study was defined to evaluate the primary energy intensity of cereals, cow milk and bull meat production in northwest Iran.

\section{Materials and methods}

This work is intended to make a comparison among the energy intensity of cereals, cow milk and bull meat production. The study was performed for evaluation of the energy flow in dairy farms and related feedstuff production farms in northwest Iran.

\subsection{Framework of the study}

The main framework of this study is based on the IFIAS methodology (IFIAS, 1974) for energy analysis and more detailed new guidelines for cumulative energy demand (CED) and life cycle assessment (LCA) concepts introduced respectively by the Association of German Engineers (VDI 4600, 2012) and International Standard Organisation (ISO 14040 and 14044) (2006). The investigation focused on the calculation of the energy intensity and energy output-input ratio indicators for the production of some cereals, milk and meat.

As the whole study project, the dairy farm system consisted of two individual units: the feedstuff production unit and the dairy cattle farm unit, which were investigated separately. The outputs of the first unit 
are the inputs for the second unit, both were studied according to LCA methodology (ISO 14040, 2006). Whereas most other studies were focused either on plant production or animal production, in this study, the boundaries of the dairy farming system started with the feedstuff production in feedstuff farms and ended with the production of milk, meat and manure as market products.

\subsection{Data acquisition}

Alfalfa, maize silage, maize corn, barley and oilseeds meal are the most used feedstuffs for Iranian cattle farming. Dairy farms in Iran largely have no grazing facilities. Iranian dairy farms buy the most feedstuffs from other, plant producing agricultural farms located in the same region or neighbour regions. A few feedstuffs are imported from abroad. Moghan agroindustrial company in Moghan plain (in north-western Iran) was chosen for investigating the energy efficiency of feedstuff production. The farms area under cultivation in this company was more than 45,000 ha. Energy intensity for some feedstuffs (e.g., cottonseed and soya bean) not investigated were derived from the scientific literature.

Nearly $85 \%$ of dairy cattle in Iran are kept in herds with less than 51 heads. The 24 dairy farms were selected representative of prevailing dairy farming methods in north-western Iran. Cattle and bull in the region are crossbreeds of Holstein and a local breed, with different degrees of breed purity. Data were gathered for 2008, 2009 and 2010.

\subsection{Energy equivalents}

A wide range of assumptions for energy equivalents has been made in energy studies. The energy equivalents used in this study for direct energies (e.g. for Diesel 47.8 MJ $1^{-1}$ ) were taken from Ortiz-Canavate and Hernanz (1999), except for electricity which was corrected to 8.4 MJ $\mathrm{kWh}^{-1}$. Human work was not viewed as an energy input. Machine equivalents were calculated using the method of Bowers (1992). The building was taken into account for dairy farms by the use of $1.1 \mathrm{GJ} \mathrm{m}^{-2}$ energy equivalent (Baird et al. 1997) according to their dimensions. The energy equivalent of fertilisers was taken from Helsel (1992) which was for $\mathrm{N}$ fertiliser 78.2 MJ $\mathrm{kg}^{-1}$ and pesticides were from Rathke and Diepenbrook (2006). The water consumption equivalent in channels and network irrigation systems was assumed to be $0.63 \mathrm{MJ} \mathrm{m}^{-3}$ water (Ozkan et al., 2004). The transportation equivalent was assumed to be $1.6 \mathrm{MJ} \mathrm{t}^{-1}$ $\mathrm{km}^{-1}$ of truck transportation (Hernanz and OrtizCanavate, 1999). Seed equivalents were used from Heichel (1980) and Ortiz-Canavate and Hernanz (1999).
For the energy outputs, the Higher Heating Value (HHV) of the products is considered as the energy equivalent for cereals, milk and meat. The reason to use the HHV was that the energy value of food materials in human health sciences is measured and reported by food HHV. As discussed earlier, it was assumed to be 15 (avg.), 3.15 and $8.8 \mathrm{MJ} \mathrm{kg}^{-1}$ for cereals with $15 \%$ moisture content, ECM (milk) and boneless fresh bull meat, respectively. Approximately $40-47 \%$ of the bull mass was intended to be boneless meat (Afolayan et al., 2002) and other parts of the cattle bull body were neglected. For intermediate materials, (e.g. foodstuff input to dairy farms) the energy equivalent was primary energy intensity.

\subsection{Allocation of energy input between product and by- products}

There are several patterns to allocate the energy input between product and by-products in multi-product systems. Kraatz (2009) used economical values of products for allocation and Grönroos et al. (2006) used their mass yield percent. In this study according to HHV yield of produced meat and milk and substitution of manure with chemical fertilisers, the total energy input allocation ratios were accepted to be $83 \%, 15 \%$ and $2 \%$, respectively for milk (ECM), manure and meat (cow cattle meat, other than bull meat studied here).

\subsection{Feedstuff energy input}

The feedstuff consumption data were checked by calculating the cattle demand for feed energy intake on the basis of animal nutrition knowledge (Kirchgeßner et al., 2008). The standard cattle energy intake requirements, the data on cattle live mass (LM) growing rates, and milk yield from the investigated farms were obtained from these calculations.

The cattle growing period was divided into different categories. The live mass, average daily mass gain and average metabolisable energy (ME) requirement in each category were summarised according to Kirchgeßner et al. (2008) and are shown in Table 1.

Table 1 . Average daily mass gain and metabolisable energy (ME) intake for different categories of cattle at different ages and live masses

\begin{tabular}{lccc}
\hline $\begin{array}{c}\text { Live mas (LM) } \\
(\mathrm{kg})\end{array}$ & $\begin{array}{c}\text { Age } \\
(\text { month })\end{array}$ & $\begin{array}{c}\text { Mass gain }^{\mathrm{a}} \\
(\mathrm{g} / \text { day })\end{array}$ & $\begin{array}{c}\text { ME intake } \\
(\mathrm{MJ} / \text { day })\end{array}$ \\
\hline \multicolumn{4}{c}{ Calves born at 38 kg (male or female) } \\
\hline \multicolumn{4}{c}{$0-5$} \\
\hline \multicolumn{4}{c}{ Bulls } \\
\hline $150-400$ & May-13 & 1000 \\
$400<$ & $13<$ & 1000 & 66.9 \\
\hline
\end{tabular}

${ }^{a}$ According to Kirchgeßner et al. (2008)

${ }^{\mathrm{b}}$ Average value for cattle data in this category by

Kirchgeßner et al. (2008) 
The number of days that cattle from each category stayed on the farms was calculated using the mass gain values given in Table 1 and the farm data on the live mass of each category of cattle at the beginning/end of each year and also those sold or bought from each farm. A prediction model was established to allocate the growing period of the existing cattle to the categories listed in Table 1. Then, the standard ME requirements were calculated for each cattle category. These calculated standard ME requirements were compared with the farm data of the ME consumption of each farm for each year. Based on the calculated $\mathrm{ME}$ requirements for each cattle category and the derived feedstuff rations, the embodied energy in the consumed feedstuff were allocated to the cattle categories for each farm and year of investigation.

\section{Results and discussion}

\subsection{Energy intensity of feedstuffs}

The feedstuff crops consumed by cattle farms investigated in this study are listed in Table 2 and other feedstuffs not investigated in this study are listed in Table 3. The energy intensity and allocated energy for their by-products are summarised in these tables.

For feedstuffs for which there was not enough information about production energy e.g., fish meal, fat powder, poultry meat and bone meal, their HHVs were used to calculate their energy intensity (EI). They had values of $37.9,20.9,16.7$ and $22.7 \mathrm{MJ} \mathrm{kg}^{-1} \mathrm{DM}$, respectively. The HHV-based output-input ratio (OIR) indicator was therefore assumed to be equal to 1 for these materials.

Table 2. Energy intensity (EI) of the investigated feedstuffs and allocated energy intensity to their by-products when used as feedstuff

\begin{tabular}{lc}
\hline Feedstuff & $\begin{array}{c}\mathrm{EI} \\
\mathrm{MJ} \mathrm{kg}^{-1} \mathrm{DM}\end{array}$ \\
\hline Alfalfa hay & 2.92 \\
Barley grain & $6.76^{\mathrm{a}}$ \\
Barley straw & $4.13^{\mathrm{a}}$ \\
Maize corn & 9.19 \\
Maize silage & $3.42^{\mathrm{b}}$ \\
Rapeseed (40\% oil) & 12.36 \\
Rapeseed meal & 9.25 \\
Wheat grain & $4.35^{\mathrm{a}}$ \\
Wheat bran & $3.62^{\mathrm{c}}$ \\
Wheat straw & $2.36^{\mathrm{a}}$ \\
\hline
\end{tabular}

${ }^{a}$ EI allocated based on the metabolisable energy (ME) ratio of grain and straw and consumed energies in their production;

b Weighted average of the results for summer and spring maize silage in this study according to cultivation area and yield; ${ }^{\mathrm{c}}$ Allocated EI based on the ME ratio of grain and bran.
Table 3. Energy intensity of feedstuffs not investigated in this study

\begin{tabular}{lc}
\hline Feedstuff & $\begin{array}{c}\text { EI } \\
\text { MJ kg }{ }^{-1} \mathrm{DM}\end{array}$ \\
\hline Beet (sugar beet) & $3.28^{\mathrm{a}}$ \\
Beet pulp & $2.92^{\mathrm{b}}$ \\
Beet molasses & $3.12^{\mathrm{b}}$ \\
Cottonseed (with linter) & $9.59^{\mathrm{c}}$ \\
Cottonseed hulls and gin trash & $4.38^{\mathrm{b}, \mathrm{c}}$ \\
Cottonseed meal & $7.79^{\mathrm{b}, \mathrm{c}}$ \\
Soya bean & $9.17^{\mathrm{d}}$ \\
Soya bean meal & $7.96^{\mathrm{b}}$ \\
Sunflower seed & $8.49^{e}$ \\
Sunflower meal dehulled & $3.88^{\mathrm{b}}$ \\
Tomato & $11.9^{\mathrm{f}}$ \\
Tomato pomace & $11.5^{\mathrm{b}}$ \\
\hline erived from Erdal et al. (2007); ${ }^{\mathrm{b}}$ Allocated energy \\
sity based on the metabolisable energy (ME) ratio of \\
uct and by-product; ${ }^{\mathrm{c}}$ Calculated by substitution with \\
products; ${ }^{\mathrm{d}}$ Mandal et al. (2002); ${ }^{\mathrm{e}}$ Uzunoz et al. (2008);
\end{tabular}

\subsection{Energy intensity of milk}

The ECM yield of the investigated dairy farms was $6,585 \mathrm{~kg} \mathrm{cow}^{-1} \mathrm{yr}^{-1}$, on average. The energy input for ECM produced in these 24 farms ranged widely between 5.60 and 10.11, with an average of $7.07 \mathrm{MJ} \mathrm{kg}^{-1}$. According to the mentioned allocation ratios, the mean energy intensity of ECM milk was calculated to be 5.81 $\mathrm{MJ} \mathrm{kg}^{-1}$.

According to this fact that mostly there are no grazing facilities in dairy farms in Iran, the energy intensity of milk is higher than reported by European studies e.g. the report of Kraatz (2009) for Germany with an amount of $3.54 \mathrm{MJ} \mathrm{kg}^{-1}$ with a half-day grazing plan. The energy input for live cattle and meat production

\subsection{Energy intensity of meat}

The dairy farms kept the bulls and heifers until they reached an average of $415 \pm 161 \mathrm{~kg}$ body mass when they were sold. The bulls were sold a few weeks after birth only in two of the dairy farms, and in some dairy farms, they were kept until reaching approximately $700 \mathrm{~kg}$.

The energy input to live beef cattle was their demand from direct energies and facilities. Because there was no determined consumption amount for each category in the farms, energy input from feedstuff was allocated from the total feedstuff consumption of a farm considering metabolisable energy requirement ratios of each category of cattle. According to the calculations, the energy intensity of a head of a live bull and the energy intensity per $\mathrm{kg}$ of boneless meat in each category is summarised 
in Table 4. The boneless meat is considered to be 40$47 \%$ of live mass adopted from Khalafalla et al. (2011), Afolayan et al. (2002) and Pfuhl et al. (2007).

Table 4. Energy input for live bull cattle in the dairy farms and meat produced

\begin{tabular}{cccc}
\hline \multirow{2}{*}{$\begin{array}{c}\text { Cattle } \\
\text { category }\end{array}$} & Mass (kg) & \multicolumn{2}{c}{ Energy intensity } \\
\cline { 3 - 4 } & & $\begin{array}{c}\text { Live cattle } \\
\text { GJ head }^{-1}\end{array}$ & $\begin{array}{c}\text { Boneless meat } \\
\text { MJ kg }^{-1}\end{array}$ \\
\hline Bull & 150 & 2.8 & 46.7 \\
& 400 & 12.1 & 75.4 \\
& 700 & 29.1 & 103.7 \\
\hline
\end{tabular}

According to Table 4, about boneless meat, for a bull mass of up to $400 \mathrm{~kg}$, the energy intensity was $75.4 \mathrm{MJ}$ $\mathrm{kg}^{-1}$ while it was $103.7 \mathrm{MJ} \mathrm{kg}^{-1}$ for bulls up to $700 \mathrm{~kg}$ body mass. The energy input from feedstuff was the main source of the energy input with a mean value of $80 \%$. In a bull of $400 \mathrm{~kg}$, the share of the energy input was $78 \%$ from feedstuff, $17 \%$ from direct energy, $4 \%$ from buildings, and $1 \%$ from machinery.

\subsection{Energy indices for the products}

The comparison of the energy intensity (EI) related to the dry matter (DM) shows quite clearly that cereals production needs much less energy than the production of milk and meat. For wheat, barley and maize corn the calculated EI was 4.35, 6.76 and $9.19 \mathrm{MJ} \mathrm{kg}^{-1} \mathrm{DM}$, respectively. While they provide more than $18 \mathrm{MJ} \mathrm{kg}^{-1}$ energy in the human body as their HHV. The EI for fresh milk and meat with $87.5 \%$ and $70 \%$ moisture content, was calculated to be 5.81 and more than $75.4 \mathrm{MJ} \mathrm{kg}^{-1}$, respectively. The corresponding DM related EI was 46.5 $\mathrm{MJ} \mathrm{kg}{ }^{-1} \mathrm{DM}$ for milk and $251 \mathrm{MJ} \mathrm{kg}^{-1} \mathrm{DM}$ for meat. While, for human nutrition fresh milk and meat delivered energy of just 3.15 and $8.8 \mathrm{MJ} \mathrm{kg}^{-1}$, respectively.

To make it easy to compare the consumed energy and the energy earned from food, the energy output-input ratio (OIR) index could be used. The OIR for cereals investigated here is $1.96 \mathrm{MJ} \mathrm{MJ}^{-1}$ for maize corn to 4.14 MJ $\mathrm{MJ}^{-1}$ for wheat. Where the OIR for milk (ECM) is $0.54 \mathrm{MJ} \mathrm{MJ}^{-1}$ and for meat is 0.08 to $0.12 \mathrm{MJ} \mathrm{MJ}^{-1}$ (respectively from bull up to $700 \mathrm{~kg}$ and bull up to 400 $\mathrm{kg}$ body mass). It means, from each MJ primary energy input for wheat, $4.14 \mathrm{MJ}$ energy for the human body is produced while, for milk, it is only $0.54 \mathrm{MJ}$ and for meat, it is less than $0.12 \mathrm{MJ}$.

It is obvious that human nutrition with milk and meat is much more energy expensive than to live by cereals. The high EI of meat indicates the high use of resources and related harmful effects of meat production on the environment (e.g. land use, emissions). The increasing demand for animal products in the future dramatically will affect the environment and may cause food shortage by allocating the farms to produce feedstuff instead of farm products as wheat and other crops. However, this study was done for cattle kept in an intensive manner as described above. For ruminants grazing on permanent grassland, lower energy consumption and less harmful effects on the environment can be expected. Therefore, replacing bull meat with sustainable food materials such as cereals could reduce pressure on the environment and guarantee enough food supply.

\section{Conclusion}

Primary energy consumed in different food material production in agriculture and animal husbandry is quite different. The primary energy embodied in cereals (energy intensity in $\mathrm{MJ} \mathrm{kg}^{-1}$ ) is less than in milk and meat. It is because in the animal body a huge amount of energy intake from feedstuffs is lost during the conversion into milk or meat. Furthermore, with their higher HHV cereals provide more energy for human nutrition than milk and meat. The higher energy outputinput ratio for cereals compared to animal products indicates the high use of resources and harmful environmental effects of milk and meat production. The increasing demand for animal products in the future dramatically will affect the environment and may cause a food shortage. Providing human body energy demand from cereals instead of milk and even more meat contributes to the conservation of resources and to ensure enough food supply for the increasing world population.

\section{Conflict of interest}

The authors declare no conflict of interest.

\section{Acknowledgement}

The authors would like to acknowledge the financial support provided by the University of Tabriz, Iran, and Leibniz Institute for Agricultural Engineering and Bioeconomy (ATB), Potsdam, Germany.

\section{References}

Abel, H.J. (1997). Stoff- und Energiebilanzen in der Tierproduktion. In Stoff- und Energiebilanzen in der Landwirtschaft. Kongressband des 109. VDLUFAKongresses, p. 33-50. Darmstadt: VDLUFA. [In German].

Afolayan, R.A., Deland, M.P.B., Rutley, D.L., Bottema, C.D.K., Evers, A.L., Ponzoni, R.W. and Pitchford, W.S. (2002). Prediction of carcass meat, fat and bone yield across diverse cattle genotypes using liveanimal measurements. Journal of Animal Production, 24, 13-16. 
Baird, G., Alcorn, A. and Haslam, P. (1997). The energy embodied in building materials updated New Zealand coefficients and their significance. Transactions of the Institution of Professional Engineers New Zealand (IPENZ): Civil Engineering Section, 24(1), 46-54.

Bowers, W. (1992). Agricultural field equipment. In Fluck, R.C. (Ed). Energy in farm production, Vol. 6, p. 117-129. USA: Elsevier https://doi.org/10.1016/ B978-0-444-88681-1.50015-6

Devendra, C. (2002). Crop-animal systems in Asia: future perspectives. Agricultural Systems, 71(1), 179 -186. https://doi.org/10.1016/S0308-521X(01)00043 $-9$

Erdal, G., Esengün, K., Erdal, H. and Gündüz, O. (2007). Energy use and economical analysis of sugar beet production in Tokat province of Turkey. Energy, 32 (1), 35-41.

https://doi.org/10.1016/ j.energy.2006.01.007

FAO, IFAD and WFP. (2002). Reducing poverty and hunger: the critical role of financing for food, agriculture and rural development. Rome: FAO.

FAO and WFP. (2010). The state of food insecurity in the world: addressing food insecurity in protracted crises. Rome: FAO.

Feedipedia. (2012). Animal feed resource information. Retrieved on February 12, 2013, from Feedipedia Website: www.feedipedia.org.

Feizbakhshi, M.T. and Soltani, A. (2013). Energy flow and global warming potential in maize corn farms in Gorgan district. Agricultural products journal, Agriculture and Natural Sciences Faculty, University of Gorgan, 3(6), 89-107. (In Persian).

Frorip, J., Kokin, E., Praks, J., Poikalainen, V., Ruus, A., Veermäe, I., Lepasalu, L., Schäfer, W., Mikkola, H. and Ahokas, J. (2012). Energy consumption in animal production-case study. Agronomy Research Biosystem Engineering, 10(Special Issue), 39-48.

Ghobadifar, A. (2009). Energy indices analysis by considering farm size in rainfed and irrigated wheat cultivation in Silakhor plain. University of Tabriz, MSc. Dissertation. [In Persian].

Grönroos, J., Seppäla, J., Voutilainen, P., Sewi, P. and Koikkalainen, K. (2006). Energy use in conventional and organic milk and rye bread production in Finland. Agriculture Ecosystems and Environment, 117(2), 109-118. https://doi.org/10.1016/ j.agee.2006.03.022

Heichel, G.H. (1980). Assessing the fossil energy costs of propagating agricultural crops. In Pimentel, D. (Ed). Handbook of energy utilization in agriculture, p. 27-34. Boca Raton, FL: CRC Press.
Helsel, Z.R. (1992). Energy and alternatives for fertiliser and pesticide use. In Fluck, R.C. (Ed). Energy in farm production. Vol. 6, p. 177-221. New York: Elsevier. https://doi.org/10.1016/B978-0-444-886811.50018-1

Hernanz, J.L. and Ortiz-Canavate, J. (1999). Energy for biological systems. In Kitani, O. (Ed). Energy and Biomass Engineering, CIGR Handbook of Agricultural Engineering, p. 24-39. St. Joseph, MI: ASAE.

IFIAS (1974). Energy analysis workshop on methodology and convention. Workshop report No. 6. Stockholm: International Federation of Institutes for Advanced Studies.

International Organization for Standardization. (2006). Environmental management - Life cycle assessment - Requirements and guidelines. (ISO Standard No. 14044). $2^{\text {nd }}$ ed. Geneva, Switzerland.

Khalafalla, I.E.E., Atta, M., Eltahir I.E. and Mohammed A.M. (2011). Effect of body weight on slaughtering performance and carcass measurements of Sudan Baggara bulls. Livestock Research for Rural Development, 23, 47.

Kirchgeßner, M., Roth, M., Schwartz, F.J. and Stangl, G.I. (2008). Tierernährung. 12. neu überarbeitete Auflage. Frankfurt am Main: DLG-Verlag. [In German]

Klinge, H. (1989). Brennwert, Thermophysikalische Stoffgrößen. In Blanke, W. (Ed). Thermophysikalische Stoffgrößen, 271-284. Berlin: Springer. [In German] https://doi.org/10.1007/978-3662-10545-0 6

Kraatz, S. (2009). Ermittlung der Energieeffizienz in der Tierhaltung am Beispiel der Milchviehhaltung. Berlin, Germany: Humboldt Universität zu Berlin. $\mathrm{PhD}$. Dissertation. [In German].

Mandal, K.G., Saha, K.P., Ghosh, P.K., Hati, K.M. and Bandyopadhyay, K.K. (2002). Bioenergy and economic analysis of soybean-based crop production systems in central India. Biomass and Bioenergy, 23 (5), 337-345. https://doi.org/10.1016/S0961-9534 (02)00058-2

Mohammadi, S., Maysami, M.A. and Ajabshirchi, Y. (2015). Energy consumption patterns of irrigated wheat production in Iran. Journal of Agricultural Mechanisation, 3(2), 33-42. [In Persian].

Mousavi-Avval, S.H., Rafiee, S., Jafari, A. and Mohammadi, A. (2011). Energy efficiency and cost analysis of canola production in different farm sizes. Energy and Environment, 2(5), 845-852.

Ortiz-Canavate, J. and Hernanz, J.L. (1999). Energy for biological systems. In Kitani, O. (Ed). Energy and 
Biomass Engineering, CIGR Handbook of agricultural engineering, Vol. 5, 13-24. St. Joseph, MI: ASAE.

Ozkan, B., Akcoaz, H. and Karadeniz, F. (2004). Energy requirement and economic analysis of citrus production in Turkey. Energy Conversation and Management, 45(11), 1821-1830. https:// doi.org/10.1016/j.enconman.2003.10.002

Pfuhl, R., Bellmann, O., Kühn, C., Teuscher, F., Ender, K. and Wegner, J. (2007). Beef versus dairy cattle: a comparison of feed conversion, carcass composition, and meat quality. Archiv Fur Tierzucht (Archives of Animal Breeding), 50(1), 59-70. https:// doi.org/10.5194/aab-50-59-2007

Pimentel, D. (2009). Energy inputs in food crop production in developing and developed nations. Energies, 2(1), 1-24. https://doi.org/10.3390/ en20100001

Rathke, G.W. and Diepenbrook, W. (2006). Energy balance of winter oilseed rape (Brassica Napusl) cropping as related to nitrogen supply and preceding crop. Journal of Agronomy, 24(1), 35-44. https:// doi.org/10.1016/j.eja.2005.04.003

Refsgaard, K.N., Halberg, N. and Kristensen, E.S. (1998). Energy utilization in crop and dairy production in organic and conventional livestock production systems. Agricultural Systems, 57(4), 599 -630. https://doi.org/10.1016/S0308-521X(98)00004 $-3$

Rezvani Moghaddam, P., Feizi, H. and Mondani, F. (2011). Evaluation of tomato production systems in terms of Energy use efficiency and economical analysis in Iran. Notulae Scientia Biologicae, 3(4), 58-65. https://doi.org/10.15835/nsb346279

Sami, M., Shiekh Davoodi, M.J. and Almasi, M. (2014). Analysis of energy and greenhouse gas balance as indexes for environmental. Assessment of wheat and maize farming: a case study. Acta Agriculturae Slovenica, 103(2), 191-201. https://doi.org/10.14720/ aas.2014.103.2.4

Schneider, F. (2010). Drivers of Change. Drivers: Perspectives on Change. In Steinfeld et al. (Eds). Livestock in a Changing Landscape. Vol. 1: Drivers, Consequences, and Responses, p. 3. USA: University of Chicago Press.

Stanton, T.L. and LeValley, S.B. (2010). Feed composition for cattle and sheep. Fort Collins, CO: Colorado State University.

Steinfeld, H., Gerber, P., Wassenaar, T., Castel, V., Rosales, M. and de Haan, C. (2006). Livestock's long shadow: environmental issues and options. Rome: FAO.
Taylor, C. (2000). Ökologische Bewertung von Ernährungsweisen anhand ausgewählter Indikatoren. Gießen, Germany: Justus-Liebig-Universität Gießen, Dissertation. [In German].

Ulbrich, M., Hoffmann, M. and Drochner, W. (2004). Fütterung ung Tiergesundheit. Stuttgart, Germany: Eugen Ulmer. [In German].

Uzunoz, M., Akcay, Y. and Esengün, K. (2008). Energy input-output analysis of sunflower seed (Helianthus annuus L.) oil in Turkey. Energy sources Part B: Economics, Planning and Policy, 3(3), 215-223. https://doi.org/10.1080/15567240701231834

Varone, F. and Aebischer, B. (2001). Energy efficiency: the challenges of policy design. Energy Policy, 29 (8), 615-629. https://doi.org/10.1016/S0301-4215 (00)00156-7

VDI (Verein Deutscher Ingenieure) (2012). Kumulierter Energieaufwand (KEA); Begriffe, Berechnungsmethoden (VDI Guideline 4600. Berlin: Beuth Verlag. [In German].

Wechselberger, P. (2000). Ökonomische und ökologische Beurteilung unterschiedlicher landwirtschaftlicher Bewirtschaftungsmaßnahmen und -systeme anhand ausgewählter Kriterien. 502. FAM-Bericht 43, Forschungsverband Agrarökosysteme. GFS-Forschungszentrum für Umwelt und Gesundheit. München: TU München. [In German].

Williams, A.G., Audsley, E. and Sandra, D.L. (2006). Determining the environmental burdens and resource use in the production of agricultural and horticultural commodities. Main Report and Executive Summary, Defra Research Project IS0205. Bedford: Cranfield University. 